\title{
Now You See It, Now You Don't: Faculty and Student Perceptions of Classroom Incivility in a Social Work Program
}

\author{
Angela R. Ausbrooks \\ Sally Hill Jones \\ Mary S. Tijerina
}

\begin{abstract}
Classroom incivility is identified as a concern in the higher education literature; however, the extent to which these concerns apply to social work education has not been empirically addressed. This initial, exploratory study examined the perceptions of classroom behaviors in a small convenience sample of faculty and students in one social work program. Quantitative results indicated that faculty tended to perceive incivility as generally less serious and frequent than did student participants. Qualitative findings suggested that while faculty believed they were addressing incivility, students did not. Students expressed the desires for instructors to be more aware of behaviors, especially distracting use of electronic devices, and to take stronger actions to enforce guidelines. Social work programs may need to consider developing uniform policies for addressing incivility as well as helping faculty to find more effective ways to address the problem. Future research is needed with larger, more representative samples.
\end{abstract}

Keywords: Incivility, classroom management, social work, higher education, social work ethics

\section{INTRODUCTION}

Once dismissed as a problem of elementary and secondary education, classroom incivility has been the subject of increasing concern in higher education over the past several years. Uncivil behaviors are those generally viewed as disrespectful and disruptive; they may include carrying on conversations with others during class, talking on cell phones, texting, surfing the internet, sleeping, arriving late, leaving early, and challenging the instructor about grades (Nordstrom, Bartels, \& Bucy, 2009). Asking students to assume a larger role in the learning process leads to classroom incivility in that students may become resistant if not openly hostile (Boice, 1996). Although accounts of discourteous, disrespectful, and disruptive student behaviors are growing among faculty, relatively little research has focused on classroom incivilities in higher education. According to Boice, this lack of attention on incivility in higher education may stem from instructors' embarrassment over acknowledging their inability to control classroom behavior. Additionally, structural factors may include lack of training for instructors on dealing with the problem and administrators' reluctance to publicly discuss such problems for fear of tarnishing the institution's image (Boice, 1996). In social work education, the literature is essentially silent with regard to issues of classroom incivility. Social work education programs and curricula are rooted in the profession's core values, among which are dignity and worth of the person, integrity, and importance of human

\footnotetext{
Angela R. Ausbrooks, Ph.D., is an Assistant Professor and Sally Hill Jones, Ph.D., and Mary S. Tijerina, Ph.D., are

Associate Professors, all in the School of Social Work at Texas State University-San Marcos. 
relationships (NASW, 2008). Acknowledging problems of classroom incivility in social work education poses the risk of considering how well social work educators are socializing students to the profession as well as raising questions about the appropriateness of students relative to professional identity and fit.

\section{LITERATURE REVIEW}

A number of factors have been identified as contributing to uncivil classroom behavior in higher education. Some authors believe classroom incivility is related to an overall decline in civil behavior in American society (Bjorklund \& Rehling, 2010; Connelly, 2009; Bray \& Del Favero, 2004). One obvious contributing factor is an individual's attitude regarding the appropriateness of uncivil classroom behavior. Hersch (1998) pointed out that current college students are more socially isolated than students from twenty years ago. Raised by parents who work longer hours and live very hectic lives, today's students are often forced to develop their world views and behavioral expectations in conjunction with their peers rather than adults. As a result of those generational differences, it should not be surprising that students and instructors often have markedly different views regarding what constitutes appropriate behavior. The widespread use of electronic mail, texting, and tweeting may serve to further compound the sense of social isolation. The impersonality associated with the use of contemporary communication tools may provide students with few cues about how to effectively navigate in the "real" social world (Hernandez \& Fister, 2001). Consequently, some students may see nothing wrong in behavior that others perceive as uncivil.

Another contributing factor to uncivil classroom behavior is a consumer orientation to the educational process. Students who hold a consumer orientation toward their education tend to feel that the main purpose for college is economic, a means to increase their earning potential (Delucchi \& Korgen, 2002). Indeed, students' motivations for attending college have shifted significantly in recent years. According to the 2006 Higher Education Research Institute's report, 69\% of students surveyed indicated that they attended college to earn more money (as opposed to acquiring knowledge)—a marked increase from 21\% in 1976 (Higher Education Research Institute, 2006). Consistent with this notion, Baker, Comer, and Martinak (2008) note that automatic and inherent respect for college professors, which was once based on the perception of them as experts in their respective fields, has been replaced by students' perceptions of their professors as merely employees of the university to which the students pay money. Hence, the perception among some students has become "I'm paying your salary, and I expect an A" (Baker et al., p. 66). According to Delucchi and Smith (1997), an emphasis on obtaining good grades in order to make more money has led to "grade grubbing" where students dispute deservedly low grades. Some students thus perceive themselves as consumers or customers rather than learners. Embracing the concept that "the customer is always right," consumer-oriented students may feel that they are entitled to act in whatever manner they choose (including incivility) since they have paid for the privilege. This relationship was confirmed by Nordstrom et al. (2009) who found that students with a consumer orientation toward the educational process also reported engaging in uncivil classroom behaviors. Among their findings, males were more likely to hold a consumer 
orientation compared to females. Additionally, students who were less involved with their classes and colleagues (e.g., part-time students, those working many hours off campus and spending less time on their classes) were also more likely to hold consumerism beliefs as well as engage in uncivil classroom behaviors.

A concept closely related to consumerism is student entitlement. Instructors often complain that students resent instructors who are challenging and demand a lot of work, and instead prefer those who are entertaining (Edmundson, 1997), approachable, and flexible (Trout, 1998). Entitlement behaviors may include students expecting good grades, even when the work they submit does not meet standards; expecting instructors to be available to them at all times and prepared to make accommodations for them; and blaming their instructors if they do not succeed in their academic work (Bartlett, 2004). Students with an entitlement disposition often believe that knowledge should be acquired with a minimum of effort on their part (Boice, 1996) and that they should be rewarded with high grades for simply attending class (Gose, 1997). Entitled students therefore take on a passive learner role, expecting faculty to bear more responsibility for student learning. Student entitlement has been attributed to the structure of the U.S. education system which is seen as offering many students little academic challenge prior to entrance to higher education, resulting in unrealistic expectations of work at the university level (Bettinger \& Long, 2005; Greene \& Forster, 2003).

Nordstrom et al. (2009) suggest that another possible predictor of classroom incivility is narcissism, defined by Akhtar and Thompson (1982) as "a concentration of psychological interest in the self” (p. 12). Self-preoccupation of narcissistic individuals is manifested in a lack of empathy for others. Further, according to the DSM-IV-TR criteria, narcissists often have a sense of entitlement, holding unrealistic expectations for favorable treatment or automatic compliance with their expectations. "They expect to be catered to and are puzzled or furious when this does not happen” (APA, 2000, p. 659). Nordstrom et al. did in fact find that students with narcissistic tendencies were likely to report engaging in uncivil behavior in the classroom.

Differing perceptions between students and faculty regarding what constitutes problem behaviors have been primarily attributed to generational differences between the two groups (Baker et al., 2008; Connelly, 2009). While most faculty are members of the Baby Boomer and Generation X generations, the majority of today's students are members of the Millennial generation. In contrast to the characteristically strong work ethic of the Baby Boomers, a characteristic of Millennials is the expectation of rewards for any performance, regardless of quality (Baker et al., 2008). Parents of Millennials who have praised and rewarded their children for mediocre and substandard performance have created the expectation that others will do the same (Twenge, 2006; Zaslow, 2007).

In addition to generational differences, gender and ethnicity differences may also result in problematic student behaviors in the classroom. Alexander-Snow (2004) reported that the degree of classroom incivility may be determined by the professor's gender and ethnicity. Problem behaviors may include Caucasian students "folding arms across the chest, slumped posture in the chair prior to...initial introduction of their teacher" when that teacher is a person of color (p. 26). Students may also begin 
questioning the instructor's authority and developing expectations of the instructor's behavior based on pre-determined values and belief systems regarding how people of the identified ethnicity are supposed to conduct themselves. Alexander-Snow adds that "the extent of the students' undermining behavior will lessen or intensify depending on whether the teacher's behaviors are in accordance with students' own cultural expectations” (p. 27).

It is not only students who can create problems with classroom incivilities, however. Several authors report that faculty too can contribute to the problem (Alberts, Hazen, \& Theobald, 2010; Alexander-Snow, 2004; Bayer, 2004). According to Braxton and Bayer (1999), faculty behaviors such as "condescending negativism, inattentive planning, moral turpitude, particularistic grading, personal disregard, uncommunicated course details, and uncooperative cynicism” (p. 21) can provoke student incivilities. Bayer (2004) believes that "the dynamic of classroom incivility is perhaps frequently a synergistic one involving inappropriate behavior on the part of students often combined with, or prompted by, misfeasance or malfeasance of the college teacher...” (p. 78). Bayer also found that faculty who mistreat students experience higher incidences of disrespectful student behavior. Regardless of the initiator, classroom incivility is harmful to the classroom climate and prohibitive to quality instruction and learning.

How faculty respond to instances of classroom incivility is also important. Schneider (1998) argues that students rarely get punished for committing incivilities, providing little

disincentive for antisocial behavior. Tenure expectations may discourage or restrict faculty members from confronting incivilities. Hogan (2007) suggests that instructors' attempts to avoid negative evaluations by students lead to failure to confront uncivil behavior and ultimately to a weakening of discipline. Alternately, faculty simply may not know how to handle problematic situations (Sorcinelli, 1994), or they may feel uncertain that they will be supported by higher authorities if they punish misbehaviors, particularly as universities compete for students and seek to avoid lawsuits. Generally, students expect professors to step in and control disruptive behaviors and have little respect for instructors who do not (Kuhlenschmidt, 1999; Young, 2003). Thus, investigating classroom incivilities and ways to respond to them is important.

\section{PURPOSE AND AIMS}

The present exploratory study seeks to address some of the gaps identified in the literature regarding classroom incivility, particularly in the context of social work education. Specifically, we examine perceptions of faculty and students concerning the type, frequency, and severity of classroom behaviors that may be perceived as uncivil. Our aims are to identify differences, if any, in perceptions between faculty and students, examine gender and ethnicity based patterns, and identify and/or develop strategies for addressing the problem of classroom incivility. A beginning exploration of such patterns may guide efforts towards further research aimed at understanding the nature of classroom incivility, assisting faculty in dealing with classroom problems, and identifying ways to help students understand behavioral expectations and their roles in preparing to enter this value-driven profession. 


\section{CONTEXT OF THE STUDY}

The study was conducted in a school of social work located in a large Southwestern state. The program is fully accredited by the Council on Social Work Education and offers both the Bachelor and the Master of Social Work degrees. Although the school offers online MSW classes, only the on-campus student population was included in the study. In the academic year during which the study was conducted, the on-campus undergraduate and graduate enrollment totaled 213 students. The faculty included 27 individuals, including 10 tenured faculty, seven tenure-track faculty, three clinical faculty, and seven adjunct faculty. Faculty in the program traditionally teach across both undergraduate and graduate levels. However, for purposes of the study, faculty responded from the perspective of the courses they typically teach.

\section{METHOD}

\section{Sampling Procedure}

A convenience sample was obtained from all faculty and on-campus students in the department of social work. Fliers were posted on faculty and student bulletin boards announcing the study, and emails were sent to all faculty and students inviting participation. Surveys with return envelopes were placed in all faculty and student mailboxes. Students were instructed to deposit completed surveys in a locked, slotted box labeled "Student Civility Survey" which was placed in the main office on top of the student mail folder file cabinet. Faculty returned surveys to the authors' mailboxes in the department office.

Faculty sample. Fifteen faculty members returned completed surveys for a $56 \%$ faculty response rate. The faculty sample included 10 females (66.7\%) and five males (33.3\%). Participants were asked to indicate their ages by selecting one of several age categories. The median age was 41.4 years, with $80 \%$ falling in the 41 to 60 year range. Ten respondents reported their race/ethnicity as Caucasian (66.7\%), two as African American (13.3\%), two as Hispanic (13.3\%), and one as Asian (6.7\%). Seven participants were tenured (46.6\%), while four were tenure-track (26.7\%), and five were clinical or adjunct faculty (27.7\%). Participants were asked to report their years of teaching experience, with categories ranging from zero to three years to 20 or more years. The median number of years of teaching experience was 9.3, with $33.3 \%$ reporting eight to eleven years of teaching experience and another peak of $26.7 \%$ reporting 20 or more years of teaching experience. The demographics of the faculty sample composition were representative of the faculty as a whole. Faculty members were also asked how much training they had received in classroom management. Almost half reported having received no training $(46.7 \%, n=7)$, and another quarter $(26.7 \%, n=4)$ stated they had received between one and three hours of training. The remainder $(26.6 \%, n=4)$ reported having received from seven to more than 10 hours of training. All faculty members reported that they taught required courses, while $26.7 \%$ also taught elective courses. Approximately three-quarters (73.3\%) reported teaching both undergraduate and graduate courses, while $20 \%$ reported teaching only graduate and $6.7 \%$ only undergraduate. 
Student sample. Of 213 student surveys distributed, only 28 were returned for a response rate of $13 \%$. Because of the low response rate, and in order to assess comparability to the student population, comparisons were made to the population of social work students enrolled in the same semester. The sample differed in demographic characteristics from the social work student population enrolled at that time. Considerably more males, older students, and students of color chose to participate in the study than were enrolled. Although a sample this nonrepresentative of the larger population may be considered biased, for purposes of this exploratory study, the authors believe there is value in examining perceptions of this group of nontraditional and ethnic minority students who evidently felt strongly enough about the civility issues to participate.

Table 1: $\quad$ Student Sample Comparison to Larger Student Population

\begin{tabular}{lcc}
\hline Demographic Characteristic & $\begin{array}{c}\text { Study Sample \% } \\
(N=28)\end{array}$ & $\begin{array}{c}\text { On Campus Social Work } \\
\text { Students \% }(N=213)\end{array}$ \\
\hline Gender & 78.6 & 90.1 \\
Female & 21.4 & 9.9 \\
Male & & 69.0 \\
Age & 28.6 & 19.2 \\
$20-30$ years & 32.1 & 11.8 \\
$31-40$ years & 39.3 & 9.4 \\
$41-50$ years & & 28.1 \\
Race/Ethnicity & 17.8 & 0.9 \\
Black/African American & 25.0 & 0.9 \\
Hispanic/Latino/a & 3.6 & 59.7 \\
American Indian/Alaska Native & 3.6 & \\
Asian/Pacific Islander & 50.0 & 43.7 \\
Caucasian & & 56.3 \\
Academic Status & 32.1 & 51.7 \\
Undergraduate & 67.9 & 48.3 \\
Graduate & & \\
Full-Time/Part-Time (MSW) & 67.9 & \\
Full-time & 32.1 & \\
Part-time & & \\
\hline
\end{tabular}

\section{Measures}

With approval from the university Institutional Review Board and the author of the instrument, a self-report survey, Classroom Civility and Teaching Practices Survey 
(Black, Wygonik, \& Frey, in press) was adapted for use in the present study. Revisions to the original survey consisted of removal of one item (wearing hats) and addition of one item (joking inappropriately). In both quantitative and qualitative formats, the survey asks participants about the seriousness and frequency of disruptive behaviors, the most frequent and troublesome behaviors, and preferred strategies for addressing these behaviors.

For quantitative measures, the survey provides a list of 25 student behaviors and asks participants to rate the behaviors for seriousness and then for frequency using a Likert scale of one to four, with four representing the most serious and most frequent. From the list of 25 disruptive behaviors and a separate list of 23 strategies for promoting civility, participants were asked to identify the three most troublesome behaviors and the three most effective strategies for dealing with the three behaviors identified. The survey also included demographic items, items regarding the types of courses taught and number of years teaching experience for faculty, questions about the perceived seriousness and perceived frequency of classroom incivility in general (not specified by type), and perceived effect of class size and gender of students on frequency of classroom incivility. Faculty were asked whether graduate or undergraduate students exhibited more incivility, and students were asked whether more incivility occurred in required or elective courses. Cronbach's alpha on the survey items addressing seriousness and frequency of behavior ratings was .88. Because this is an initial exploratory study with a small sample, data analysis was focused on response frequencies, some statistical comparison of faculty and student responses, and qualitative analysis.

\section{QUANTITATIVE RESULTS}

\section{General Behavior Seriousness, Frequency, and Characteristics}

Participants were asked to rate the seriousness and frequency of disruptive or uncivil behaviors in their classes in general (non-specific as to type of behavior). As seen in Table 2, faculty appeared to view the problem of incivility as less serious and less frequent than did student respondents. Each rating category was assigned a code of one to five, with one being least serious and frequent and five being most serious and frequent. Significant differences were found between faculty and student mean responses as determined by independent samples $t$-tests. The faculty mean rating of seriousness (1.9, $S D=0.9, n=15)$ was significantly lower than the student mean rating $(2.8, S D=1.2, n=$ 28; $t(41)=-2.4, p=.02)$. Similarly, the faculty mean rating of behavior frequency (2.7, $S D=1.3, n=15)$ was significantly lower than the student mean $(3.8, S D=1.4, n=27 ; t$ $(40)=-2.6, p=.01)$.

Several survey items asked about characteristics of students more likely to behave disruptively and situations in which these behaviors would more likely occur. More faculty $(46.7 \%)$ than students (25\%) reported that gender made no difference, while more students $(64.3 \%)$ than faculty $(40 \%)$ reported females were more likely to disrupt class. Faculty were asked to compare the frequency of uncivil behaviors among graduate and undergraduate students. Almost half (46.7\%) reported that undergraduate students behaved disruptively more than did graduate students, while $40 \%$ said there was no 
difference, and 13.3\% did not respond. Students (46.4\%) reported that incivility occurred more frequently in large classes, while the same proportion, $46.4 \%$, said there was no difference. Half (50\%) of the students said there was no difference in frequency of incivility between required or elective courses, while $35.7 \%$ reported that these behaviors occurred more frequently in required courses.

Table 2: $\quad$ General Behavior Seriousness and Frequency Comparisons

\begin{tabular}{lcc}
\hline Behavior Measure & $\begin{array}{c}\text { Faculty } \% \\
(N=15)\end{array}$ & $\begin{array}{c}\text { Students \% } \\
(N=28)\end{array}$ \\
\hline Seriousness & 33.3 & \\
Not at all & 46.7 & 14.3 \\
Slightly & 13.3 & 28.6 \\
Moderately & 6.7 & 32.1 \\
Very & 0.0 & 14.3 \\
Extremely & & 10.7 \\
Frequency & 20.0 & \\
Does not occur & 26.7 & 10.7 \\
Once per semester & 33.3 & 7.1 \\
Several times per semester & 6.7 & 14.3 \\
One to two times a month & 13.3 & 21.4 \\
Once a week or more & 0.0 & 42.9 \\
Missing & & 3.6 \\
\hline
\end{tabular}

\section{Behavior Seriousness and Frequency: Comparisons of Faculty and Students}

Participants were provided with a list of 25 disruptive behaviors and asked to rate their seriousness, if they were to occur in their classrooms, on a scale of one to four, where a rating of four indicated "very serious" and a rating of one was "not serious" (Table 3). Although faculty rated the seriousness of disruptive behaviors actually occurring in their classes in general as significantly less serious than did students, when it came to rating the seriousness of specific behaviors, should they occur, the two groups' ratings were comparable, with some exceptions. Faculty mean ratings of the seriousness for 19 of the 25 behavior items were the same as or slightly higher than student ratings. However, faculty rated text-messaging, allowing the cell phone to ring, and dressing inappropriately as slightly less serious than did students. Larger differences between faculty and student ratings were found in higher faculty mean ratings of the seriousness of reading the newspaper, sleeping, using vulgarity, making threats to faculty or students, verbally attacking, and physically attacking other students. Faculty mean ratings for 16 of the 25 behaviors were rated three or higher, indicating they perceived these behaviors as more serious, compared to 11 behaviors rated that seriously by students. 
Table 3. Behavior Seriousness and Frequency: Comparison of Faculty and Student Mean Ratings

\begin{tabular}{|c|c|c|c|c|}
\hline \multirow[b]{2}{*}{ Behavior } & \multicolumn{2}{|c|}{$\begin{array}{c}\text { Behavior Seriousness } \\
\text { Mean (SD) }\end{array}$} & \multicolumn{2}{|c|}{$\begin{array}{c}\text { Behavior Frequency } \\
\text { Mean (SD) }\end{array}$} \\
\hline & $\begin{array}{l}\text { Faculty } \\
(N=15)\end{array}$ & $\begin{array}{l}\text { Student } \\
(N=28)\end{array}$ & $\begin{array}{l}\text { Faculty } \\
(N=15)\end{array}$ & $\begin{array}{l}\text { Student } \\
(N=26)\end{array}$ \\
\hline Verbal attacking other students & $4.0(0.0)$ & $3.4(1.1)$ & $1.2(0.4)$ & $1.6(0.9)$ \\
\hline Physically attacking other students & $4.0(0.0)$ & $3.3(1.3)$ & $1.0(0.0)$ & $1.0(0.0)$ \\
\hline Making threats to faculty/students & $4.0(0.0)$ & $3.3(1.3)$ & $1.1(0.3)$ & $1.1(0.4)$ \\
\hline Computer use unrelated to class & $3.5(0.9)$ & $3.3(1.1)$ & $2.2(1.1)$ & $2.8(1.1)$ \\
\hline Taking phone calls in class & $3.6(0.5)$ & $3.2(1.0)$ & $1.7(1.0)$ & $2.0(0.9)$ \\
\hline Text-messaging & $3.2(0.8)$ & $3.3(0.8)$ & $2.5(0.9)$ & $3.5(0.7)$ \\
\hline Allowing cell phone to ring & $2.9(0.9)$ & $3.1(0.9)$ & $1.8(0.9)$ & $2.4(1.0)$ \\
\hline Groans/sighs & $2.3(0.8)$ & $2.3(1.0)$ & $1.5(1.0)$ & $2.3(0.8)$ \\
\hline Sleeping & $3.4(1.0)$ & $2.5(1.3)$ & $1.6(1.0)^{\mathrm{a}}$ & $1.3(0.5)$ \\
\hline Acting bored or apathetic & $2.9(0.8)$ & $2.7(1.0)^{\mathrm{c}}$ & $1.9(1.2)^{\mathrm{a}}$ & $2.6(0.9)$ \\
\hline Reading the newspaper & $3.3(1.0)$ & $2.1(1.0)$ & $1.2(0.4)$ & $1.2(0.4)$ \\
\hline Using vulgarity & $3.5(0.9)$ & $2.8(1.3)$ & $1.2(0.6)^{\mathrm{a}}$ & $1.5(0.6)$ \\
\hline $\begin{array}{l}\text { Challenging teacher's credibility/ } \\
\text { knowledge }\end{array}$ & $3.0(0.8)$ & $2.7(1.1)$ & $1.3(0.6)$ & $2.0(1.0)$ \\
\hline $\begin{array}{l}\text { Sending inappropriate emails to } \\
\text { faculty }\end{array}$ & $3.5(0.7)$ & $3.1(1.3)$ & $1.3(0.5)$ & $1.0(0.0)$ \\
\hline Making sarcastic remarks & $3.3(0.7)$ & $3.1(1.0)$ & $1.7(1.0)$ & $2.2(1.0)$ \\
\hline Making offensive remarks & $3.8(0.4)$ & $3.3(1.3)$ & $1.3(0.6)$ & $1.5(0.8)$ \\
\hline Joking inappropriately & $3.0(0.7)^{\mathrm{a}}$ & $2.8(1.2)$ & $1.3(0.6)$ & $1.5(0.8)^{b}$ \\
\hline $\begin{array}{l}\text { Talking to other students at } \\
\text { inappropriate times }\end{array}$ & $3.1(0.4)$ & $3.1(0.9)$ & $2.7(1.0)$ & $3.0(1.0)$ \\
\hline $\begin{array}{l}\text { Talking out of turn or interrupting } \\
\text { others }\end{array}$ & $2.9(0.6)$ & $2.9(0.8)$ & $2.3(1.0)$ & $2.6(1.0)^{\mathrm{b}}$ \\
\hline Arriving late or leaving early & $3.0(0.7)$ & $2.9(1.0)$ & $2.5(1.1)$ & $2.9(0.9)$ \\
\hline Unpacking or packing backpacks & $1.9(0.7)$ & $1.5(0.7)$ & $2.0(1.0)$ & $2.2(1.1)$ \\
\hline Eating & $1.5(0.8)$ & $1.3(0.5)$ & $2.8(1.1)^{\mathrm{a}}$ & $3.6(0.8)$ \\
\hline Wearing distracting clothing & $2.2(0.9)$ & $2.0(1.1)$ & $1.6(0.9)$ & $1.4(0.8)$ \\
\hline Dressing inappropriately & $2.1(0.9)$ & $2.3(1.3)$ & $1.3(0.8)$ & $1.3(0.7)$ \\
\hline Poor hygiene or offensive odor & $2.5(0.7)$ & $2.4(1.2)$ & $1.1(0.3)$ & $1.3(0.6)$ \\
\hline
\end{tabular}


Participants also rated the frequency of the 25 behavior items they observed or experienced most often, on a scale of one to four, where a rating of one represented "infrequent (one time or less per semester)" and four represented "quite frequent (one or more times per week)" (Table 3). While the faculty mean rating of incivility frequency in their classes in general was significantly lower than that of students, when it came to rating the frequency of specific behaviors they have observed, the mean ratings of the two groups were comparable, again with some exceptions. Faculty mean ratings of 20 of the 25 behaviors were the same as or only slightly lower than students' ratings. However, faculty rated sleeping, sending inappropriate emails, and wearing distracting clothing as slightly more frequent than did students. The largest differences between faculty and student ratings of frequency were the higher student mean ratings of text-messaging, groans/sighs, eating, acting bored or apathetic, and challenging the teacher's credibility or knowledge. While student mean ratings of 11 of the behaviors were higher than two, the mid-range rating, six behaviors were rated that frequently by faculty.

\section{Most Troublesome Behaviors and Instructor Strategies}

Participants were asked to identify from the provided list of 25 behavior items those that were both most troublesome and occurred most frequently in their classrooms. They were also provided a list of strategies instructors could use to address disruptive behaviors and asked to choose three strategies that would be most effective for each troublesome and frequent behavior selected. Frequencies were computed and compared for faculty and students. There were considerable commonalities in the responses of both groups, as seen in Table 4.

Three behaviors reported by faculty and students as among those most troublesome were talking to other students at inappropriate times, texting, and computer use for tasks unrelated to class. Among the most frequently listed troublesome behaviors identified by faculty but not students were arriving late or leaving early and talking out of turn or interrupting others.

Among the strategies most commonly selected as those most effective for instructors to use in addressing troublesome behaviors, the top choice for both groups was speaking privately with the offending student. Both also listed speaking publicly to the offender and addressing the entire class. Faculty included stating expectations clearly, while students listed sending an email to the offender.

In summary, quantitative results indicated a general trend of faculty viewing disruptive behaviors as less serious and frequent than did students. Within this trend, there were many points of agreement on ratings of specific behaviors, which were the most troublesome behaviors, and preferred strategies to address behaviors. However, there were also potentially important differences.

Faculty and students appeared to agree that several behaviors warranted little attention. These included behaviors viewed as serious but rare (aggressive behaviors, sleeping or reading the newspaper in class, vulgar or offensive remarks), frequent but not serious (eating in class), and both infrequent and not serious (dress or hygiene issues). 
Table 4. Most Troublesome Behaviors and Preferred Strategies: Faculty/ Student Comparison

\begin{tabular}{|c|c|c|}
\hline \multirow[b]{2}{*}{ Ranking } & \multicolumn{2}{|c|}{ Most Troublesome Behaviors } \\
\hline & Faculty & Students \\
\hline \multirow[t]{2}{*}{1} & Arriving late/leaving early $(n=8)$ & Texting $(n=16)$ \\
\hline & $\begin{array}{l}\text { Talking to other students at } \\
\text { inappropriate times }(n=8)\end{array}$ & \\
\hline 2 & Texting $(\mathrm{n}=5)$ & Computer use unrelated to class $(n=11)$ \\
\hline \multirow[t]{3}{*}{3} & $\begin{array}{l}\text { Talking out of turn or interrupting } \\
\text { others }(\mathrm{n}=4)\end{array}$ & $\begin{array}{l}\text { Talking to other students at inappropriate } \\
\text { times }(n=9)\end{array}$ \\
\hline & Computer use unrelated to class $(n=4)$ & \\
\hline & \multicolumn{2}{|c|}{ Strategies to Address Behaviors } \\
\hline Ranking & Faculty & Students \\
\hline 1 & Speak privately with student $(n=23)$ & Speak privately with student $(n=50)$ \\
\hline 2 & State expectations clearly $(n=17)$ & Address entire class $(n=31)$ \\
\hline 3 & Speak publicly to offender $(n=15)$ & Send email to offender $(n=12)$ \\
\hline 4 & Address entire class $(n=12)$ & Speak publicly to offender $(n=11)$ \\
\hline
\end{tabular}

Faculty and students seemed to agree that other behaviors were both fairly serious and frequent, indicating they need effective intervention. Distracting behaviors such as talking to students at inappropriate times, talking out of turn, and arriving late or leaving early were rated as mid-range to high in seriousness and frequency by both groups. These behaviors were also among those listed as most troublesome behaviors that occur frequently.

There were several behaviors, however, that faculty and students agreed were serious but students viewed as occurring more frequently than did faculty. These included behaviors indicating boredom such as acting apathetic or groaning, challenging the teacher's credibility, and technology-related behaviors. Computer use unrelated to class and text-messaging, while rated high in seriousness and listed in the most troublesome behaviors by both groups, were seen as occurring much more frequently by students than faculty. Therefore, these differences in perceptions point to potential areas needing attention.

\section{QUALITATIVE RESULTS}

In addition to the forced-response, quantitative items, the survey included several open-ended questions. The qualitative questions elicited participants' perceptions of the most serious and most common disruptive behaviors observed, instructors' responses to these behaviors, strategies instructors can/should utilize to address disruptive behaviors, 
whether personal characteristics (age, gender, race/ethnicity) of the instructor affect behavior, whether observed behaviors affected teaching and learning, and reasons students engage in disruptive behaviors. Participants were also given the opportunity to provide additional comments. A content analysis was conducted on participants' qualitative responses. Faculty and student responses to each of the open-ended questions are reported below. Each response was considered a unit of analysis, however, participants may have provided several responses to each question. Therefore, response totals may exceed the number of participants who responded to qualitative questions.

\section{Most Serious Behaviors}

When asked to describe the most serious cases of classroom incivility/disruption observed and/or experienced, four (27\%) faculty identified "disrespect toward the teacher and the students," two (13\%) identified "texting," and two considered an "angry outburst" and "emotional breakdown in class" as the most serious behavior. Two faculty reported observing no incidents in field placement courses. Of those faculty who observed/experienced classroom incivility, 10 (67\%) reported most incidents of incivility occurring in undergraduate classes, two (13\%) in graduate courses, and one faculty reported that incivility/disruption is an uncommon occurrence in field seminars. Examples of faculty responses included the following: (a) "A student that felt persecuted by peers and faculty and was regularly vocal about these feelings of persecution;" (b) "Angry argument/outburst to the extent that immediate intervention and follow-up counseling were required;" (c) "Student giving herself manicure and pedicure during guest lecture.”

Based on responses to open-ended items, students reported observing serious incidents of classroom incivility as occurring more frequently than did faculty. Behaviors students reported as among the most serious included "surfing the internet" $(n=6,21 \%)$; "checking Facebook" ( $n=6,21 \%)$; "disrespect of teachers and students" ( $n=6,21 \%)$; "talking on cell phones during class" $(n=4,14 \%)$; "texting” ( $n=3,11 \%)$; and "talking during class" ( $n=2,7 \%)$. Two individual students identified additional behaviors which were "students coming into class late," and "noise," specifically related to large classes. Examples of student comments were: (a) Students using their computers to check their facebook status or using their phones to [check] Facebook;" (b) "Someone talking on the phone during class;" (c) "In a fairly large policy class this semester, I'm sitting in the back and the last three or four rows are all frenzy of texting, internet surfing, passing notes, and gossiping. All while the instructor is lecturing."

\section{Most Commonly Observed/Experienced Disruptive Behaviors}

The most common type of incivility/disruption observed by faculty was "side conversations" ( $n=6,40 \%)$. Other behaviors reported as most commonly observed were "texting” ( $n=3,20 \%)$; “arriving late/leaving early" ( $n=3,20 \%)$; and "rude behavior toward peers" ( $n=3,20 \%)$. Two (13\%) faculty reported the most common behavior they have experienced was students openly challenging them in class. In addition, "eye rolling," "surfing the internet," "talking on cell phones," and "apathy" were each identified by four different faculty members. Sample faculty comments included: (a) 
"The most common are students whispering to each other during class;" (b) "Students being rude to others;" (c) "Surfing net on laptop unrelated to course; taking phone calls and leaving class; coming late to class."

Behaviors cited as most commonly observed by students included "texting" ( $n=8$, 29\%); "talking during class" ( $n=5,18 \%)$; and "disrespect toward the instructor" $(n=3$, $11 \%)$. Several students cited behaviors related to use of the computer as the most common. These included "surfing the internet" $(n=3,11 \%)$, and "checking Facebook during class" ( $n=3,11 \%)$. Several behaviors were reported as most common by six different students. They included: "arriving late/leaving early," "disrespecting another student," "not being prepared for class and asking questions," "expressing bias during class discussions," "talking on the cell phone during class," and "electronics" in general. Sample student comments included the following: (a) "Texting is common, but not necessarily disruptive. There are a few people though who do it constantly and openlythat is when it's disruptive;" (b) "One of those students (described elsewhere) made a very judgmental, hateful comment about people who shop at Wal-Mart...how the people who shop there cannot afford babysitters so they bring their 'wild' children and let them run around. It was incredibly out of line and shocking coming from an MSW student."

Six (40\%) faculty reported not having experienced incivility/disruptive behavior in their classes. They attributed this to "providing clear expectations" ( $n=4,27 \%)$; "modeling desired/appropriate behavior for students" ( $n=1,7 \%)$; the fact "students are engaged and understand the rules" ( $n=1,7 \%)$, "the instructor places a greater focus on professionalism and expectations" ( $n=1,7 \%)$, and "the maturity level of students during their field practicum" ( $n=1,7 \%)$. However, one faculty member believed that if anyone had not experienced incivility/disruptive behavior in their classes, they were "not being honest."

\section{Measures Taken by Faculty to Address Disruptive Behavior}

Faculty and student perceptions differed regarding the measures instructors took to address disruptive behaviors previously identified. Of the faculty responses regarding measures they take to address disruptive behaviors $(n=14,93 \%)$, they reported that they "address observed behaviors with specific students" $(n=5,33 \%)$; "with the entire class" ( $n=4,27 \%)$; "by reviewing pre-determined rules and expectations" ( $n=3,20 \%)$; "physically inserting themselves in close proximity to the students engaging in incivility/disruptive behaviors" ( $n=2,13 \%)$; "taking control of the class" ( $n=1, .07 \%)$; "changing the syllabus and highlighting expectations" ( $n=1,7 \%)$; and "providing personal examples (of disruptive behavior)" ( $n=1,7 \%)$. Examples of faculty comments follow: (a) "Take control of discussion. Speak with student privately;" (b) "Changed syllabus to reflect expectations and consequences; verbal redirection in class;" (c) "Move over to the areas of the room where they are located, and that usually results in their stopping their 'visiting' without causing further disruption by 'scolding' them in front of whole class."

Comments by students regarding measures taken by faculty to address disruptive behaviors included reports that the majority of their instructors "did nothing" to address 
incivility/disruptive behaviors ( $n=9,32 \%)$; and most instructors "ignored the behavior" $(n=4,14 \%)$. Of these 13 students reporting inaction on the part of faculty, three reported having only one instructor who addressed incivility/disruptive behaviors. Additional faculty responses to disruptive behavior as reported by students included "instructors addressed the behaviors with the entire class" ( $n=5,14 \%)$; "the instructor regained the focus of the class" ( $n=2,7 \%)$; "instructor held down the noise while others spoke" $(n=$ $1,4 \%)$; "not sure the instructor was aware the behavior occurred" ( $n=1,4 \%)$; and "the teacher was involved in the incident" ( $n=1,4 \%)$. Sample comments by students included: (a) "Texting is ignored by all instructors with the exception of Dr. X. She asks the student to please turn off the phone;" (b) "They didn't do anything. Dr. X has a bell she uses to get the classes' attention. Sometimes this works. I'd suggest a stun gun!” (c) "The professor was involved in the incident. The professor was trying to make/persuade the students about the topic. The students would not back down and eventually the professor suggested they speak after class."

\section{Suggested Strategies for Proactive Measures by Faculty}

Asked to identify proactive measures that instructors can use to promote a positive environment, eight (53\%) faculty members suggested "establishing rules," "putting expectations on the syllabus," and "setting high expectations at the beginning of the class" as the most effective strategies. Four (27\%) faculty believed "role modeling behavior" and "treating students with respect" are the best strategies. Another three (20\%) faculty members suggested "encouraging dialogue" and "beginning class with questions and concerns of students" as a method to promote a positive environment. Other strategies identified by three individual different faculty included: "using humor," "being assertive," and "having students sign a contract."

Students suggested several strategies instructors can utilize to promote a positive environment. Twelve (43\%) students suggested instructors should "take charge/be in control" which would include "stating and enforcing the rules," "providing expectations for phone and computer usage," and "applying penalties." Five (18\%) students believed the instructor should talk to the student or class, and one (4\%) suggested instructors should "address behavioral issues early." Additional suggestions included "unprepared students should ask questions during office hours" ( $n=1,4 \%)$; "instructors should treat students with respect and as adults" ( $n=1,4 \%)$; "instructors should teach the textbook material" ( $n=1,4 \%)$; and "instructors should walk around the room and rearrange tables" ( $n=1,4 \%)$. Only one (4\%) student believed "the instructor should ignore disruptive behaviors." Sample student comments included: (a) "Reminding all students that they have a responsibility to fellow students and to their professor to act in accordance with school code of conduct or face further consequences. If that doesn't work put them on suspension or kick them out. In a master's program we are, or should all be, professionals;" (b) "Walk around room, rearrange tables so they can view what is on computer. Insist phones are put away. Send person out of class and try again next week." 


\section{Age, Gender and Race/Ethnicity Patterns}

Faculty were divided as to whether age, gender, race/ethnicity of the instructor affected the incidence of incivility/disruptive behaviors. Of the faculty who responded to this open-ended item, four (27\%) believed these factors could increase disruptive behaviors, especially if the faculty member was African American $(n=2,13.5 \%)$, female and/or ethnic minority female ( $n=2,13.5 \%)$, and older $(n=1,6.8 \%)$. Four (27\%) faculty indicated they weren't sure whether these factors would affect the occurrence of incivility/disruptive behaviors. Sample comments included the following: (a) "I think so, and it is also affected by the demographics of the disruptive student. The only time I have been questioned on my knowledge and credibility was by an older white male student. I don't think that would have happened if I was white and male;" (b) "I have heard from faculty of color that there is more challenging of their credibility coming from students."

Students ( $n=12,43 \%)$ also offered opinions about the impact of instructor characteristics on the incidence of classroom incivility. Eight of these students believed personal characteristics of faculty did not contribute to the presence of disruptive behaviors. However, two students believed these factors did affect the presence of disruptive behaviors, specifically if the instructor was older, African American, and female. Comments included: (a) "I believe age, gender, race/ethnicity play a part for everyone involved," (b) "I have noticed a lack of respect toward an older female, African American professor by younger students."

In addition, three (17\%) students stated that instructor and student characteristics can be factors in uncivil behavior: (a) It's the overachieving high strung females;" (b) "Unfortunately, these students are 'nontraditional', meaning over 30-ish. I know these girls well, and they definitely have attitudes of superiority and feel as if they have 'earned their place here"”; (c) "I hate to think so. However, in Dr. X's class - she's African American, older, and less inclined to confront. Seems out-of-control in her class.”

\section{Effect of Incivility on Teaching and Learning}

In response to the open-ended question about whether incivility/disruption affected their teaching, six (40\%) faculty reported that incivility made them more vigilant $(n=2)$, pay more attention to the atmosphere $(n=1)$, be more determined to keep the class focused $(n=2)$, and learn from their mistakes $(n=1)$. Three $(20 \%)$ faculty reported losing their focus and becoming distracted when they experience disruptive behavior, and two (13\%) faculty indicated they become more defensive, angry, and offended. One (4\%) faculty member stated his/her teaching is not affected by classroom incivility. Examples of faculty comments included: (a) "Yes - in the past and in the classroom. It has made

me more vigilant, less impulsive and less excited about the classroom experience...;" (b) "I find myself coming more defensive when there is an atmosphere of hostility or disinterest from several students. I may respond with sarcasm and that, of course, leads to a further downward spiral in class morale. Thank goodness this is not a frequent pattern;" (c) "Yes - it's distracting. I wonder about students' interest. I wrestle with how to handle. I get angry and feel offended at times. So, it takes energy and focus away from course objectives.” 
Nine students (32\%) reported that the occurrence of disruptive behaviors caused them to lose or have difficulty maintaining their focus, and/or become distracted. Five (18\%) students reported these behaviors were disruptive, two (18\%) considered them annoying, two (18\%) identified them as a waste of time, and one student (4\%) described the behaviors as stifling to his/her learning. One (4\%) student reported getting angry when observing disruptive behaviors, and another (4\%) admitted to engaging in uncivil behavior when disruption occurs. Five (18\%) students indicated they are not affected at all by classroom incivility. Sample comments from students included: (a) "I've selected seats away from repeat offenders. One semester, I sat behind a student who social networked in Facebook the whole three hours. Her computer was constantly flashing new images that was disruptive to my concentration of the lecture;" (b) "It has made many hours this semester a waste of my time. It is frustrating to work hard to meet expected goals as given to us well in advance only to arrive to the packed-to-capacity classroom and hear the extension granted because one person found the schedule too challenging;" (c) "Yes. I act bored and in turn, [I] text during class because I feel unchallenged."

\section{Reasons Students Engage in Disruptive Behaviors}

Faculty and students offered a myriad of reasons students engage in incivility/disruptive behaviors. Faculty responses included: student entitlement $(n=3$, $20 \%)$; not being held accountable $(n=3,20 \%)$; boredom $(n=2,13 \%)$; students having their own agenda ( $n=2,13 \%)$; professors being uncomfortable with authority $(n=2$, $13 \%)$; and professors wanting to be friends with students $(n=2,13 \%)$. Individual respondents $(n=1,7 \%)$ identified each of the following reasons for students' disruptive behaviors: generational differences, students not being taught appropriate behavior, students not being provided clear expectations, students not being invested, student narcissism, power issues, students seeking attention, identity issues, students being comfortable with each other, and student conflict spilling over into the classroom. Examples of faculty comments included: (a) "Sense of entitlement. 'I paid for this class. It's my business how I act...;" (b) "The natural narcissism of youth, enhanced by overlydoting parents, and a general breakdown in civility and respect for authority (and authority figures);" (c) "Sometimes generational differences - checking phone, e-mail, texting is like breathing or drinking water. Lack of clear expectations or enforcement from instructor. Material not engaging student interest."

Students' responses were similar, and they identified additional reasons. Students' perceptions of reasons their peers engage in disruptive behaviors included: lack of interest and boredom ( $n=4,14 \%)$; weren't taught better $(n=2,7 \%)$; unaware of their behavior ( $n=2,7 \%)$, and lack of respect and rude $(n=4,14 \%)$. Individual students $(n=$ $1,4 \%)$ stated each of the following reasons for disruptive behaviors: think they know more than the instructor and their peers; lack discipline, push limits and haven't dealt with demons, generational differences, self-centeredness, technology trends, immaturity, too many people in a small space, no consequences, and no attention span. Only one student described being unsure why students engage in disruptive behaviors. Sample comments included: (a) "Lack of respect and consideration, not being aware that it's disruptive;" (b) "Immaturity of students; general lack of respect for those in authority; 
generational;" (c) "Boredom/burned out - we hear a lot of the same subjects/issues/topics in every class...," (d) "Because they lack discipline and are not held accountable. They also avoid instructors that do hold them accountable."

In summary, the major finding from the qualitative data is the difference in perceptions between faculty and students regarding faculty's responses to incidents of incivility. Faculty reported that they address the behaviors with individual students and/or with the entire class. However, students overwhelmingly report that faculty do not address disruptive behaviors. One possible explanation for this could be that faculty report addressing disruptive behaviors much more than they do because they don't want to be perceived as unable to manage their classrooms, as suggested by Boice (1996). Another possibility is that faculty are not observing all the behaviors students observe because they are in the front of the classroom engaged in pedagogical activitieslecturing, conducting powerpoint presentations, and writing information on the classroom board. Therefore, computer and telephone screens are not visible, and uncivil behaviors are not evident. Although it is possible that students are correct regarding their reports of faculty inaction, it should be noted that students have no way of knowing if faculty addressed behavioral problems with students privately.

The qualitative and quantitative findings are similar in terms of the students identifying behaviors as occurring more frequently than did faculty and more of a focus on technology-related behaviors by students. Disrespect was mentioned quite frequently by both faculty and students, including peer-to-peer disrespect, which may need more focus. An additional significant finding is the difference in faculty and student perceptions of how disruptive behaviors should be addressed. This supports the quantitative findings regarding student and faculty desires for behaviors to be addressed verbally with individual students. However, qualitative data appear to indicate that students want faculty to engage in much more direct and punitive methods to address and resolve disruptive behaviors exhibited by their peers. Students want faculty to address these behaviors openly and remove perpetrators from the classroom.

\section{DISCUSSION}

\section{Limitations}

The ability to generalize the findings of this study to other populations is limited by the small and non-representative sample from one social work program. Nevertheless, this study represents an initial attempt to empirically explore the issue of classroom civility. As such, the aim of the study was not to generate generalizable results but rather to obtain a beginning understanding of the issue of classroom incivility in social work education. The fact that the student sample was not representative of the student body of the social work department from which it was drawn, however, is informative. The demographics of the students who chose to respond suggest the possibility that some students feel strongly about incivility in the classroom, in particular older, male, AfricanAmerican, and graduate students. This profile suggests generational and power differences in that older students and those from ethnic minority groups may be less likely to hold attitudes of entitlement than do traditional age, non-minority students. 


\section{Implications and Recommendations}

The findings, although preliminary and based on a small sample, indicate that incivility may be an issue social work students and faculty observe and struggle with in ways similar to that described in the literature. Faculty and students in this study identified reasons for these behaviors similar to those reported in the higher education literature. Several findings warrant the attention of social work faculty in terms of classroom management and research. It is possible that at least some students observe disruptive behaviors that faculty do not and are bothered by them, desiring faculty to take stronger stands in managing behaviors, as found by others (Hogan, 2007; Kuhlenschmidt, 1999; Schneider, 1998; Young 2003). Based on participants' responses, faculty could utilize these findings to gain insight into students' perceptions related to faculty's classroom management or lack thereof. The findings also suggest that some students want to be aware of consequences implemented for disruptive behaviors. Although it may not always be feasible to provide students with this information, it appears there is a need to ensure students understand that there are consequences for disruptive behavior and that these will be enforced. Faculty and students agreed that this can be accomplished by clearly articulating in the syllabus the course expectations and associated consequences and reviewing these with students at the beginning of the course and several times throughout the semester.

There are many variables possibly at play in disruptive behaviors, as the literature indicates. Generational differences between instructors and students may mean a gap in definitions of civility. Drawing from the seminal work of Mannheim (1952, as cited in Joshi, Dencker, Franz, \& Martocchio, 2010), Joshi et al. define age-based generational identity as "membership in an age group that shares collective memories developed during the formative years of life" (p. 398). The underlying assumption is that the process of growing up during a particular era impacts an individual's attitudes and that these attitudes are shared by all those born in the same time period. While the majority of social work faculty in the present study represent the Baby Boomer generation, characterized by its strong work ethic and work-centrality, students are more likely to represent the cohort known as GenMe, Gen Y, or Millenials, i.e., those born after 1982 (Twenge, 2010). Literature on generational differences in the workplace suggests these more recent generations express a weaker work ethic, view work as less central to their lives, and seek more freedom and work-life balance than older workers (Twenge, 2010). Research specific to generational differences in personality traits relevant to the workplace consistently show increases in individualistic traits, with younger generations scoring higher on both positive individualist traits such as self-esteem and assertiveness and more negative individualistic traits such as narcissism (Twenge, 2010). It is this negative level of individualism (narcissism, defined as an inflated sense of self) that can lead to the possibility of entitlement, or expecting something for nothing.

Differences in faculty members' classroom management styles or comfort levels in dealing with conflict may suggest the need for policies that promote more uniform responses to incivility. Additionally, methods of effective engagement of students in course material may be lacking. Social work faculty may need more training in classroom management, finding effective ways to manage disruptive behaviors, setting clear 
expectations and consequences, obtaining student buy-in to behavioral guidelines, and following through with enforcement. The ubiquitous use of electronic devices, not easily detected, has brought new challenges to classroom management that also need to be addressed.

Students who participated in this study reflected underrepresented demographics of the student population in age, gender, ethnicity, and degree program (MSW). These students may have responded at a higher rate than those students who reflect more traditional/represented demographics because it was an opportunity for them to be heard. Ethnic minority students may not always speak out in class because they don't perceive they have a "voice." Participating in this study may have provided an opportunity to express their opinions anonymously without any threat or perception of risk. Therefore, another area to pursue in a larger study is whether there are significant differences in behavioral expectations of students based on gender, ethnicity, and age. The effect of faculty gender, race/ethnicity, and age also needs further investigation, as some participants in this study noticed effects catalogued by Alexander-Snow (2004).

Future research using larger, representative samples and comparisons among various social work programs will assist in determining whether these preliminary findings reflect the perceptions of a broader student base or are specific to the initial respondents who reflect underrepresented demographics in the student population. Larger samples will allow statistical analysis of relationships between demographic characteristics and perceptions of incivility. In addition, research that focuses more specifically on what incidents occur in social work classrooms, perhaps by surveying faculty and students about behaviors in individual courses immediately upon completion of those courses would determine more specifically what behaviors occur.

While the findings of this small, exploratory study are similar to those reported in the higher education literature, the implications of these results for the profession of social work also speak to socializing social work students into the profession and its values and ethics. Framing classroom incivility in terms of breaches of such core social work values as integrity, dignity and worth of persons, and the importance of human relationships may be an opportunity to instruct and shape behavior consistent with the principles and conduct of the profession in the classroom environment and beyond.

\section{References}

Alberts, H. C., Hazen, H. D., \& Theobald, R. B. (2010). Classroom incivilities: The challenge of interactions between college students and instructors in the US. Journal of Geography in Higher Education, 34(3), 439-462. doi:10.1080/03098260903502679

Akhtar, S., \& Thompson, J. (1982). Overview: Narcissistic personality disorder. American Journal of Psychiatry, 139, 12-20.

Alexander-Snow, M. (2004). Dynamics of gender, ethnicity, and race in understanding classroom incivility. New Directions for Teaching \& Learning, 99, 21-31. 
American Psychiatric Association. (2000). Diagnostic and statistical manual of mental disorders (Revised $4^{\text {th }}$ ed.). Washington, DC: Author.

Baker, S. D., Comer, D. R., \& Martinak, M. L. (2008). All I'm asking is for a little respect: How can we promote civility in our classrooms? Organization Management Journal, 5, 65-80.

Bartlett, T. (2004). Taking control of the classroom, Chronicle of Higher Education, September 17, p.8.

Bayer, A. E., (2004). Promulgating statements of student rights and responsibilities. New Directions for Teaching \& Learning, 99, 77-87.

Bettinger, E. P., \& Long, B. (2005). Remediation at the community college: Student participation and outcomes. New Directions for Community Colleges, 129, 17-26.

Bjorklund, W. L., \& Rehling, D. L. (2010). Student perceptions of classroom incivility. College Teaching, 58, 15-18.

Black, L., Wygonik, M., \& Frey, B. (in press). Faculty-preferred strategies to promote a positive classroom environment. Journal on Excellence in College Teaching.

Boice, B. (1996). Classroom incivilities. Research in Higher Education, 37, 453-485.

Braxton, J. M., and Bayer, A. E. (1999). Faculty misconduct in collegiate teaching. Baltimore: Johns Hopkins University Press.

Bray, N. J., \& Del Favero, M. (2004). Sociological explanations for faculty and student classroom incivilities. New Directions for Teaching \& Learning, 99, 9-19.

Connelly, R. J. (2009). Introducing a culture of civility in first-year college classes. Journal of General Education, 58, 47-64.

Delucchi, M., \& Korgen, K. (2002). “We're the customer---we pay the tuition”: Student consumerism among undergraduate sociology majors. Teaching Sociology, 30, 100107.

Delucchi, M., \& Smith, W. (1997). A postmodern explanation of student consumerism in higher education. Teaching Sociology, 25, 322-327.

Edmundson, M. (1997, September). On the uses of liberal education: As lite entertainment in higher education. Harper's Magazine, 295(1768), 39-50.

Gose, B. (1997). Efforts to curb grade inflation get an F from many critics. Chronicle of Higher Education, July 25, A41-A42.

Greene, J., \& Forster, G. (2003). Public high school graduation and college readiness rates in the United States. Working Paper No. 3. Center for Civic Innovation, Manhattan Institute for Policy Research.

Hernandez, T., \& Fister, D. (2001). Dealing with disruptive and emotional college students: A systems model. Journal of College Counseling, 4, 49-62. 
Hersch, P. (1998). A tribe apart: A journey into the heart of American adolescence. New York: Ballantine.

Higher Education Research Institute. (2006). The American freshmen: National norms for Fall 2005. Los Angeles: University of California, Los Angeles.

Hogan, M. (2007). The effects of perceived disruptive behavior on classroom civility. Fayetteville, AR: University Ombuds Office, University of Arkansas.

Joshi, A., Dencker, J. C., Franz, G., \& Martocchio, J. J. (2010). Unpacking generational identities in organizations. Academy of Management Review, 35(3), 392-414.

Kuhlenschmidt, S. L. (1999). Promoting internal civility: Understanding our beliefs about teaching and students. New Directions for Teaching \& Learning, 77, 13.

National Association of Social Workers. (2008). NASW code of ethics: Guide to the everyday professional conduct of social workers. Washington, DC: Author.

Nordstrom, C. R., Bartels, L. K., \& Bucy, J. (2009). Predicting and curbing classroom incivility in higher education. College Student Journal, 43(1), 64-85.

Schneider, A. (1998). Insubordination and intimidation signal the end of decorum in many classrooms. Chronicle of Higher Education, 44(29), pp. A12-A14.

Sorcinelli, M. D. (1994). Dealing with troublesome behaviors in the classroom. In K. W. Prichard \& R. M. Sawyer (Eds.), Handbook of college teaching: Theory and application (pp. 365-373). Eastport, CT: Greenwood Press

Trout, P. (1998). Point of view: Incivility in the classroom breeds 'education lite'. Chronicle of Higher Education, July 24, p. A40.

Twenge, J. M. (2006). Generation me: Why today's young Americans are more confident, assertive, entitled-and more miserable than ever before. New York: Free Press.

Twenge, J. M. (2010). A review of the empirical evidence on generational differences in work attitudes. Journal of Business Psychology, 25, 201-210. doi:10.1007/s10869010-9156-6

Young, J. (2003). Sssshhh. We're taking notes here. Chronicle of Higher Education, August 8, p. A29-30.

Zaslow, J. (2007, July). Blame it on Mr. Rogers: Why young adults feel so entitled. Wall Street Journal (Online). Retrieved from http://online.wsj.com/article/SB118358476840657463.html

\section{Author note:}

Address correspondence to: Angela Ausbrooks, School of Social Work, Health Professions Building, 150A, Texas State University-San Marcos, San Marcos, TX 786664616. Email: aa16@txstate.edu 